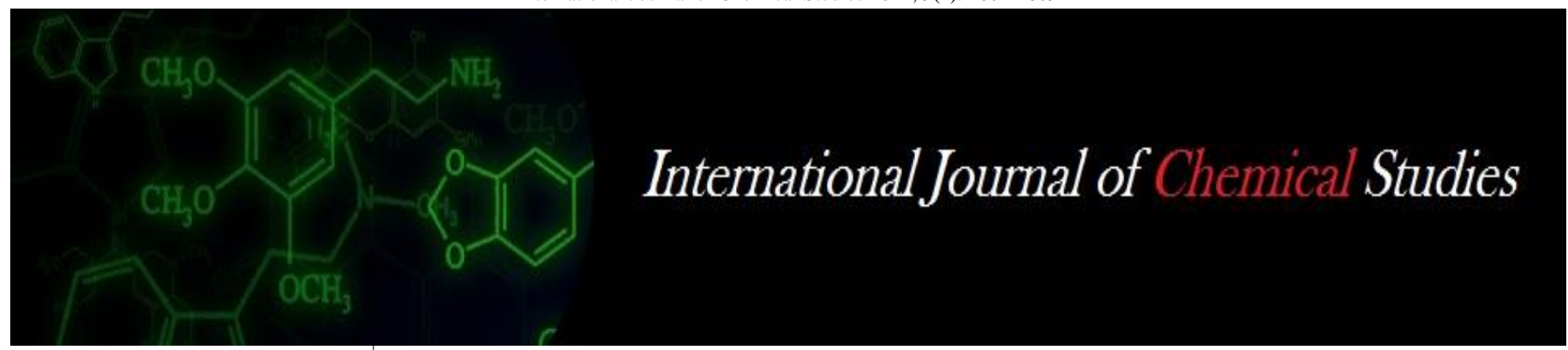

P-ISSN: 2349-8528

E-ISSN: 2321-4902

www.chemijournal.com

IJCS 2021; 9(1): 2801-2809

(C) 2021 IJCS

Received: $21-10-2020$

Accepted: 30-12-2020

Sunandana Mandal

Department of Soil Science and Agricultural Chemistry, Palli

Siksha-Bhavana, Visva-Bharati

Sriniketan, West Bengal, India

Goutam Kumar Ghosh

Department of Soil Science and

Agricultural Chemistry, Palli

Siksha-Bhavana, Visva-Bharati

Sriniketan, West Bengal, India

Corresponding Author: Sunandana Mandal

Department of Soil Science and Agricultural Chemistry, Palli

Siksha-Bhavana, Visva-Bharati Sriniketan, West Bengal, India

\section{Depth-wise distribution of macronutrients (N, P, $K, S)$ and their correlation with soil properties in selected soil profiles of Birbhum district of West Bengal, India}

\section{Sunandana Mandal and Goutam Kumar Ghosh}

DOI: $\underline{\text { htps://doi.org/10.22271/chemi.2021.v9.i1am.11651 }}$

\begin{abstract}
The present study was undertaken to assess the vertical distribution of macronutrients viz., nitrogen $(\mathrm{N})$, phosphorus $(\mathrm{P})$, potassium $(\mathrm{K})$ and sulphur $(\mathrm{S})$ in relation to soil properties in five selected soil profiles, one each from Suri II $\left(\mathrm{P}_{1}\right)$, Rampurhat II $\left(\mathrm{P}_{2}\right)$, Md Bazar $\left(\mathrm{P}_{3}\right)$, Nalhati I $\left(\mathrm{P}_{4}\right)$ and Sainthia $\left(\mathrm{P}_{5}\right)$ block of Birbhum district of West Bengal. These five soil profiles were collected from the paddy growing areas of Birbhum district. The soil texture varied from silt loam to silt. Based on the fertility ratings, $\mathrm{pH}$ of soils was strongly acidic to neutral in nature. Its value ranged from 5.01-7.07. Electrical conductivity (EC) value ranged from $0.06-0.12 \mathrm{dS} / \mathrm{m}$. Its values were in safe limits $(<0.1 \mathrm{dS} / \mathrm{m})$ in the study area. The Organic carbon content was more in surface horizons than in sub-surface horizons. $\mathrm{pH}$ and EC followed increasing trend with decrease in depth along the profiles. The available macronutrients varied from $75.26-275.97 \mathrm{~kg} / \mathrm{ha}$ for available N, 8.65-25.22 kg/ha for available P, 137.55-310.32 kg/ha for available $\mathrm{K}$ and $1.03-3.01 \mathrm{mg} / \mathrm{kg}$ for available $\mathrm{S}$. The available macronutrients decreased with increasing depth in all the profiles. The available $\mathrm{N}$ and $\mathrm{P}$ were low to medium and $\mathrm{S}$ was low in status. High to medium $\mathrm{K}$ content was found at surface layer in all five soil profiles whereas at lower depth its value was found to be low to medium. Macronutrients showed decreasing trend with increase in depth. $\mathrm{pH}$ showed significant and negative correlation with all the macronutrients, whereas organic carbon showed significant and positive correlation.
\end{abstract}

Keywords: Paddy growing soils, correlation studies, macronutrient status, physico- chemical properties, Birbhum district, West Bengal

\section{Introduction}

Macronutrients are important for plant growth as they play major roles in biological processes. These nutrients are the building block of all proteins, including the enzymes, which actually control the biological processes. Root growth and development of plant is enhanced with a good supply of macronutrients. Uptake of other nutrients is also influenced by the application of macronutrients. Soil macronutrients are important for improving crop growth. Out of sixteen plant nutrients, $\mathrm{N}, \mathrm{P}, \mathrm{K}$ and $\mathrm{S}$ are referred as macronutrients as they are required in a large number of physiological processes of the plant. These processes are growth of plant, increase in plant productivity, Increase in leaf and grain yield. By supplying the elements, macronutrient deficiency can be corrected which are essential for normal plant growth. By continuous cropping, nutrients are removed from soils. Runoff can cause nutrient loss. Crop growth and development is restricted due to poor organic carbon content of soil and deteriorated soil physical properties, which is the result of intensive cropping and imbalanced use of essential plant nutrients. Hence the deficiency of the macronutrients appears to be a threat to the population of the world. The application of fertilizers in crop production requires a detailed knowledge of the soil nutrient status. The availability of nutrients in soil depends upon soil $\mathrm{pH}$, organic matter, adsorptive surfaces and other physical, chemical and biological conditions in the rhizosphere (Jiang et al., 2009) ${ }^{[14]}$. Soil testing provides the information about the nutrient status of the soil, which is helpful for fertilizer recommendation. We always consider the importance of distribution of the nutrients in the top soil. But plants take nutrients from sub-surface layer of the soil as well. Therefore, the knowledge of vertical distribution of 
nutrients is very important in recommending management practices (Sankar and Dadhwal, 2009) ${ }^{[38]}$. Processes such as leaching, weathering, dissolution, atmospheric deposition cause different distribution pattern of the nutrients along vertical direction. Therefore the present study was undertaken to know the vertical distribution of macro nutrient status of soil of Birbhum district, West Bengal and an attempt was also made to correlate macro nutrients content of the soils with other soil properties. The vertical variation of $\mathrm{N}, \mathrm{P}, \mathrm{K}$ and $\mathrm{S}$ is the result of the profile distribution of the parent materials from which they are derived or soil aggregations or concretions (Srinivasan et al., 2013) ${ }^{[48]}$. Vertical distribution of nutrients may be altered by changing soil management. The depth of accumulation of a particular nutrient and its amount that accumulates also depends on rainfall and leaching. Present investigation was useful to determine the deficiency of the macronutrients along surface layer as well as subsurface layer of the soil and thereby use of fertilizers depending on the status of the macronutrients.

\section{Materials and Methods}

Birbhum is the $9^{\text {th }}$ biggest district by area in West Bengal by occupying $5.12 \%$ of the total area of the state. The geographical area of the district is $4545 \mathrm{sq}$. $\mathrm{km}$. The district is situated between $23^{\circ} 32^{\prime} 30^{\prime \prime}$ (right above the tropic of cancer) and $24^{\circ} 35^{\prime} 0^{\prime \prime}$ north latitude and $87^{\circ} 5^{\prime} 25^{\prime \prime}$ and $88^{\circ} 11^{\prime} 40^{\prime \prime}$ east longitudes. The district is triangular in shape. State Jharkhand is at the north and west border and Murshidabad district is at the east border of Birbhum. During summer, the temperature can shoot well above $40^{\circ} \mathrm{C}\left(104^{\circ} \mathrm{F}\right)$ and in winters it can drop to around $10^{\circ} \mathrm{C}\left(50^{\circ} \mathrm{F}\right)$ (Mondal, 2006) ${ }^{[26]}$. The main vegetation of the district is rice. The soils of Birbhum district are derived from granite, gneiss, schist, and sand stone, shale parent rocks on gently to undulating geomorphic surfaces. These soils are dominantly classified as Alfisols, Ultisols and Oxisols occurring in association with Entisols and Inceptisols. These soils are well drained and acidic with lower cation exchange capacity and organic matter content and have mixed or kaolinitic clay mineralogy enriched with sesquioxides.
Five selected soil profiles, one each from Sainthia, Suri II, Rampurhat II, Md Bazar and Nalhati I block of Birbhum district of West Bengal were collected from rice growing areas of the district at three different depths viz., 0-15 cm, 15$30 \mathrm{~cm}$ and $30-60 \mathrm{~cm}$ (Table-4). Collected soil samples were stored in polythene bags for laboratory analysis. After grinding, the soil samples were passed through $2 \mathrm{~mm}$ sieve. Following the method as proposed by Bouyoucos (1927) ${ }^{[6]}$, particle size distribution (relative distribution of sand, silt and clay in soils) and textural class was determined. $\mathrm{pH}, \mathrm{EC}$ of the collected soil samples were determined following the method as proposed by Jackson (1973) ${ }^{[13]}$. Organic carbon content of the collected soil samples were determined using Wet digestion method as suggested by Walkley and Black (1934) ${ }^{[54]}$. Available $\mathrm{N}$ content of the soil samples was estimated by Kjeldahl distillation process using alkaline permanganate solution, following the method as described by Subbiah and Asija (1956) ${ }^{[49]}$. Available $\mathrm{P}_{2} \mathrm{O}_{5}$ (kg/ha) was extracted using the method proposed by Bray and Kurtz (1945) in acidic soils whereas Olsen extractant $\left(0.5 \mathrm{M} \mathrm{NaHCO}_{3}\right.$ at $\left.\mathrm{pH} 8.5\right)$ was used for analysing neutral to alkaline soils as described by Olsen et al., (1954) ${ }^{[33]}$. Available K was extracted by $1 \mathrm{~N}$ ammonium acetate at $\mathrm{pH} 7$, then determined with help of flame photometer using K-filter (Jackson, 1973) ${ }^{[13]}$. Available $\mathrm{SO}_{4}-\mathrm{S}$ was extracted using $0.15 \%$ calcium chloride $\left(\mathrm{CaCl}_{2} \cdot 2 \mathrm{H}_{2} \mathrm{O}\right)$ as an extractant (Williams and Steinbergs, 1959) ${ }^{[55]}$. As per the limits suggested by Arora (2002), the soil samples were classified into low, medium and high categories for available N, P and K. Available S was rated based on the limits proposed by Hariram and Dwivedi (1994) [11] (Table-1). The soil samples were classified depending on the soil $\mathrm{pH}$ values and EC values as proposed by Muhr et al., (1965) ${ }^{[27]}$ (Table-2 and 3). Correlation analysis was carried out to detect functional relationship between soil physicochemical properties and macronutrients using a statistical software IBM SPSS 25.0 and Microsoft Office Excel 2007 (Microsoft Corporation, USA). The level of significance in the results is $P<0.05$. Correlation analysis was carried out by using Pearson's method.

Table 1: Rating Chart of Macronutrients in soil required for Plant growth

\begin{tabular}{|c|c|c|c|c|}
\hline Parameters & Low & Medium & High & Reference \\
\hline Organic Carbon $(\%)$ & $<0.50$ & $0.5-1.0$ & $>1.0$ & Muhr et al., (1965) ${ }^{[27]}$ \\
\hline Available $\mathrm{N}(\mathrm{kg} / \mathrm{ha})$ & $<280$ & $280-560$ & $>560$ & Arora $(2002)$ \\
\hline Available $\mathrm{P}_{2} \mathrm{O}_{5}(\mathrm{~kg} / \mathrm{ha})$ & $<10$ & $10-25$ & $>25$ & Arora $(2002)$ \\
\hline Available $\mathrm{K}_{2} \mathrm{O}(\mathrm{kg} / \mathrm{ha})$ & $<118$ & $118-280$ & $>280$ & Arora $(2002)$ \\
\hline Available $\mathrm{S}(\mathrm{mg} / \mathrm{kg})$ & $<10$ & $10-20$ & $>20$ & Hariram and Dwivedi $(1994){ }^{[11]}$ \\
\hline
\end{tabular}

Table 2: Classification of Soil $\mathrm{pH}$ values

\begin{tabular}{|c|c|c|c|c|c|c|}
\hline Strongly Acid & Moderately acid & Slightly Acid & Neutral & Moderately Alkali & Strongly Alkali & Reference \\
\hline$<5.5$ & $5.5-6.0$ & $6.0-6.5$ & $6.5-7.5$ & $7.5-8.5$ & $>8$ & Muhr et al., (1965) $)^{[27]}$ \\
\hline
\end{tabular}

Table 3: Classification of total soluble salts $\left(\mathrm{EC} \mathrm{dSm}^{-1}\right)$

\begin{tabular}{|c|c|c|c|c|}
\hline No deleterious effect on crop & Critical for germination & Critical for Salt Sensitive Crop & Injurious to most crops & Reference \\
\hline$<1.0$ & $1.0-2.0$ & $2.0-3.0$ & $>3.0$ & Muhr et al., (1965) ${ }^{[27]}$ \\
\hline
\end{tabular}

Table 4: Geographical Locations of the Collected Profile Soil Samples

\begin{tabular}{|c|c|c|c|c|c|}
\hline Serial No & Depth of Soil $(\mathrm{cm})$ & Block & Mouza & Latitude & Longitude \\
\hline $\mathrm{S}_{1}$ & $0-15$ & \multirow{3}{*}{ Suri II $\left(\mathrm{P}_{1}\right)$} & \multirow{3}{*}{ Purandarpur } & \multirow{3}{*}{$23^{\circ} 51^{\prime} \mathrm{N}$} & \multirow{3}{*}{$87^{\circ} 35^{\prime} \mathrm{E}$} \\
\hline $\mathrm{S}_{2}$ & $15-30$ & & & & \\
\hline $\mathrm{S}_{3}$ & $30-60$ & & & & \\
\hline $\mathrm{S}_{4}$ & $0-15$ & \multirow{3}{*}{ Rampurhat II $\left(\mathrm{P}_{2}\right)$} & \multirow{3}{*}{ Morgram } & \multirow{3}{*}{$24^{\circ} 80^{\prime} \mathrm{N}$} & \multirow{3}{*}{$87^{\circ} 52^{\prime} \mathrm{E}$} \\
\hline $\mathrm{S}_{5}$ & $15-30$ & & & & \\
\hline $\mathrm{S}_{6}$ & $30-60$ & & & & \\
\hline
\end{tabular}




\begin{tabular}{|c|c|c|c|c|c|}
\hline $\mathrm{S}_{7}$ & $0-15$ & \multirow{3}{*}{$\operatorname{Md} \operatorname{Bazar}\left(\mathrm{P}_{3}\right)$} & \multirow{3}{*}{ Md Bazar } & \multirow{3}{*}{$23^{\circ} 58^{\prime} \mathrm{N}$} & \multirow{3}{*}{$87^{\circ} 32^{\prime} \mathrm{E}$} \\
\hline $\mathrm{S}_{8}$ & $15-30$ & & & & \\
\hline $\mathrm{S}_{9}$ & $30-60$ & & & & \\
\hline $\mathrm{S}_{10}$ & $0-15$ & \multirow{3}{*}{ Nalhati I ( $\left(\mathrm{P}_{4}\right)$} & \multirow{3}{*}{ Nalhati I } & \multirow{3}{*}{$24^{\circ} 16^{\prime} \mathrm{N}$} & \multirow{3}{*}{$87^{\circ} 58^{\prime} \mathrm{E}$} \\
\hline $\mathrm{S}_{11}$ & $15-30$ & & & & \\
\hline $\mathrm{S}_{12}$ & $30-60$ & & & & \\
\hline $\mathrm{S}_{13}$ & $0-15$ & \multirow{3}{*}{ Sainthia $\left(\mathrm{P}_{5}\right)$} & \multirow{3}{*}{ Sainthia } & \multirow{3}{*}{$23^{\circ} 58^{\prime} \mathrm{N}$} & \multirow{3}{*}{$87^{\circ} 40^{\prime} \mathrm{E}$} \\
\hline $\mathrm{S}_{14}$ & $15-30$ & & & & \\
\hline $\mathrm{S}_{15}$ & $30-60$ & & & & \\
\hline
\end{tabular}

\section{Results and Discussion}

\section{Physico-chemical Properties of Soil}

Five soil profiles are studied and named as Suri II $\left(\mathrm{P}_{1}\right)$, Rampurhat II $\left(\mathrm{P}_{2}\right)$, Md Bazar $\left(\mathrm{P}_{3}\right)$, Nalhati I $\left(\mathrm{P}_{4}\right)$ and Sainthia $\left(\mathrm{P}_{5}\right)$. Particle size distribution and textural class of the soil profiles are presented in Table-5. Among the different soil fractions viz., sand, silt and clay, the later two fractions appeared to be the major ones in all five soil profiles. The textural class was found to be silt loam, silt, silt, silt loam and silt respectively in Suri II, Rampurhat II, Md Bazar, Nalhati I and Sainthia at all three depths. Percentage of silt, sand and clay fractions varied from 75.00-84.00, 3.00-13.50 and 11.5015.50 respectively. Studies showed that with increasing depth, finer fractions of soil (viz., silt and clay fractions) increase whereas decreasing trend was observed in case of \% sand. Although soil texture is inherent property, this might be attributed to accelerated weathering as a result of disturbance during continuous cultivation by Boke (2004) ${ }^{[5]}$. Chima (2007) ${ }^{[8]}$ reported that, although the texture is an inherent property of soil, vegetation modification could have contributed to the variations in particle size distribution. Sankar and Dadhwal (2009) ${ }^{[38]}$ reported that, clay content increased with increasing depth in pedons whereas silt and sand distribution pattern observed was irregular in red soils of Tamil Nadu. Nagendran and Angayarkanni (2010) [28] obtained that the clay and clay plus silt content increased with depth in pedons showing the migration of finer particles in the pedons of the soils of Cumbum valley, Tamilnadu. Sharma et al., (2013) ${ }^{[42]}$ reported an increasing trend of silt and clay fractions down the depth was noted in all three plains but it was more prominent in the soils of lower plains due to the process of eluviation and illuviation of soil materials in the alluvial soils of Aravalli Range. Studies given by Oladoye (2015) ${ }^{[32]}$ showed that, sand decreased with soil depth while clay increased with soil depth in all the plots. Silt did not follow a regular pattern. This explains the significant different $(\mathrm{P}>0.05)$ between the two depths. Kumar and Paliyal (2016) ${ }^{[20]}$ reported under pasture lands, sand tended to accumulate in the surface i.e. it decreased with increase in soil depth. The silt content in cultivated lands increased with increase in soil depth. In pasture lands it tended to increase up to certain depth but the content were lowest at the lowermost depths i.e. mostly beyond one meter depth in the soils of Spiti valley in Himachal Pradesh. The increasing tendency of clay with depth in pasture lands may be due to leaching during snowmelt. Pastures are generally located at mountain tops or comparatively at higher elevation as compared to cultivated lands and hence receive enough and regular snowfall whereas, it is very occasional in cultivated lands which are generally at lower valleys. Results obtained by Kunlanit (2018) [3] indicated that soil texture was finer with increasing depth with the exception of the paddy land. Finer soil texture is observed with increasing depth which is due to the leaching of clay from upper layer to the lower layers.

Table 5: Particle Size Distribution and Textural Class of the Profile soils of the Selected Blocks of Birbhum District (Mandal et al., 2019) ${ }^{[23]}$.

\begin{tabular}{|c|c|c|c|c|c|}
\hline Serial No. & Soil Depth (cm) & \% Sand & $\%$ Silt & \% Clay & Textural Class \\
\hline \multicolumn{6}{|c|}{ Profile $1\left(P_{1}\right)$ Suri II } \\
\hline $\mathrm{S}_{1}$ & $0-15$ & 13.50 & 75.00 & 11.50 & Silt Loam \\
\hline $\mathrm{S}_{2}$ & $15-30$ & 4.50 & 82.00 & 13.50 & Silt Loam \\
\hline $\mathrm{S}_{3}$ & $30-60$ & 4.00 & 80.50 & 15.50 & Silt Loam \\
\hline \multicolumn{6}{|c|}{ Profile $2\left(\mathbf{P}_{2}\right)$ Rampurhat II } \\
\hline $\mathrm{S}_{4}$ & $0-15$ & 8.10 & 80.00 & 11.90 & Silt \\
\hline $\mathrm{S}_{5}$ & $15-30$ & 6.30 & 81.00 & 12.70 & Silt \\
\hline $\mathrm{S}_{6}$ & $30-60$ & 3.40 & 83.00 & 13.60 & Silt \\
\hline \multicolumn{6}{|c|}{ Profile $3\left(\mathbf{P}_{3}\right)$ Md Bazar } \\
\hline $\mathrm{S}_{7}$ & $0-15$ & 6.80 & 81.20 & 12.00 & Silt \\
\hline $\mathrm{S}_{8}$ & $15-30$ & 5.00 & 82.50 & 12.50 & Silt \\
\hline $\mathrm{S}_{9}$ & $30-60$ & 3.00 & 83.00 & 14.00 & Silt \\
\hline \multicolumn{6}{|c|}{ Profile $4\left(\mathbf{P}_{4}\right)$ Nalhati I } \\
\hline $\mathrm{S}_{10}$ & $0-15$ & 11.00 & 76.50 & 12.50 & Silt Loam \\
\hline $\mathrm{S}_{11}$ & $15-30$ & 10.30 & 76.50 & 13.20 & Silt Loam \\
\hline $\mathrm{S}_{12}$ & $30-60$ & 10.00 & 76.50 & 13.50 & Silt Loam \\
\hline \multicolumn{6}{|c|}{ Profile $5\left(P_{5}\right)$ Sainthia } \\
\hline $\mathrm{S}_{13}$ & $0-15$ & 5.50 & 82.60 & 12.00 & Silt \\
\hline $\mathrm{S}_{14}$ & $15-30$ & 4.10 & 83.00 & 12.90 & Silt \\
\hline $\mathrm{S}_{15}$ & $30-60$ & 3 & 84 & 13 & Silt \\
\hline
\end{tabular}

Physico-chemical properties of the soil profiles are represented in Table-6. The $\mathrm{pH}$ values ranged from 5.01-6.03 in profile $1\left(\mathrm{P}_{1}\right)$; 6.46-7.07 in profile $2\left(\mathrm{P}_{2}\right)$; 5.03-6.98 in profile $3\left(\mathrm{P}_{3}\right) ; 6.42-6.98$ in profile $4\left(\mathrm{P}_{4}\right) ; 5.79-6.54$ in profile $5\left(\mathrm{P}_{5}\right)$. As per the limits suggested by Muhr et al., (1965) ${ }^{[27]}$ soils were found to be strongly acidic to neutral in soil reaction. The increased $\mathrm{pH}$ with increasing depth of soil profiles was ascribed to the deposition of exchangeable bases at lower depth of soil profiles due to heavy rainfall in the region during rainy season (Balpande et al., 2007) ${ }^{[2]}$. Sankar 
and Dadhwal (2009) ${ }^{[38]}$ reported that soil $\mathrm{pH}$ was found increasing with increasing depth. Similar results were given by Nagendran and Angayarkanni (2010) ${ }^{[28]}$ in the soils of Cumbum valley, Tamil Nadu. The slightly acidic to neutral alkaline $\mathrm{pH}$ may be attributed to the soil reaction of useful fertilizer material with soil colloids, which resulted in the reaction of basic cation on the exchangeable complex of the soil (Singh and Mishra, 2012) ${ }^{[44]}$. Naik (2014) ${ }^{[29]}$ reported that $\mathrm{pH}$ gradually increased with increasing depth of soil profile in mango grown acidic soils of Jharkhand. Mishra et al., (2015) ${ }^{[25]}$ reported in their studies that $\mathrm{pH}$ value increases with decreasing height in the soils of mid central valley at Odisha zone. Khanday et al., (2017) ${ }^{[16]}$ reported that the $\mathrm{pH}$ generally increased with increasing depth. The increase in $\mathrm{pH}$ with depth had been attributed to leaching of bases and decrease in organic matter accumulation with the extent of slope. Singh et al., (2017) ${ }^{[45]}$ reported that the reason for the varied acidity may be due to elevated precipitation resulting in the leaching losses of bases from the surface soils. In addition, the soil acidity was increased by addition of nitrogenous fertilizers and decomposition of organic residues. $\mathrm{pH}$ showed increasing trend with depth, down the profiles. Patangray et al., (2018) ${ }^{[35]}$ also reported that $\mathrm{pH}$ showed general trend of increase down the profile in soils of Yavatmal district, Maharashtra.

EC value ranged from $0.06-0.10 \mathrm{dS} / \mathrm{m}$ in profile $1\left(\mathrm{P}_{1}\right)$; 0.09 $0.12 \mathrm{dS} / \mathrm{m}$ in profile $2\left(\mathrm{P}_{2}\right) ; 0.05-0.07 \mathrm{dS} / \mathrm{m}$ in profile $3\left(\mathrm{P}_{3}\right)$; $0.05-0.07 \mathrm{dS} / \mathrm{m}$ in profile $4\left(\mathrm{P}_{4}\right) ; 0.071-0.10 \mathrm{dS} / \mathrm{m}$ in profile 5 $\left(\mathrm{P}_{5}\right)$. EC values in the study area are in safe limits $(<0.1 \mathrm{dS} / \mathrm{m})$ without any salinity/ alkalinity hazards in the topsoil. EC values followed increasing trend with depth of the profile. This can be attributed to the leaching of the cations down the soil depth by rainfall (Wong et al., 2005) ${ }^{[56]}$. EC increased with depth of profile, this might be due to the leaching of saline from soil surface through profile depth because of the irrigation in the land (Durak et al., 2010) ${ }^{[9]}$. Sharma et al., (2013) ${ }^{[42]}$ reported that the level of EC was found within the safe limit and has no adverse effect on crop growth and production in Kothari river plains in alluvial soils of Aravalli range. Oladoye (2015) ${ }^{[32]}$ observed that soil content of most of the exchangeable bases reduced down the profile. Patangray et al., (2018) ${ }^{[35]}$ observed increasing trend of EC with depth of the profile in pedon 1. Mandal and Ghosh (2020) ${ }^{[22]}$ reported that the surface soils of selected blocks of Birbhum district, West Bengal were non-saline in nature.

Organic carbon followed decreasing trend with depth in all five profiles. Its value ranged from $0.31-0.78 \%$ in profile 1 $\left(\mathrm{P}_{1}\right) ; 0.30-0.76 \%$ in profile $2\left(\mathrm{P}_{2}\right) ; 0.30-0.81 \%$ in profile 3 $\left(\mathrm{P}_{3}\right) ; 0.30-0.81 \%$ in profile $4\left(\mathrm{P}_{4}\right) ; 0.23-0.55 \%$ in profile 5 $\left(\mathrm{P}_{5}\right)$. Low to medium organic carbon content was observed at the surface layer of the profiles. Organic matter acts as a major factor regulating the availability of organic forms of $\mathrm{N}$, $\mathrm{P}, \mathrm{S}$ and trace elements in the soils, as well as to improve soil structure, infiltration rate, nutrient retention and to reduce soil erosion (Smith and Elliott, 1990) ${ }^{[46]}$. Sankar and Dadhwal (2009) ${ }^{[38]}$ observed decresing trend of soil organic carbon with increasing depth in all pedons of red soils of Tamil Nadu. Nagendran and Angayarkanni (2010) ${ }^{[28]}$ observed that the organic carbon content was low $(0.15$ to $0.69 \%)$ and decreased with depth in pedons of all soils of Cumbum valley, Tamilnadu. Naik (2014) ${ }^{[29]}$ reported that the organic carbon content gradually decreased with increase in soil depth in mango grown acidic soils of Jharkhand. The subsequent decomposition and incorporation of litter into the soil would have helped in raising the organic carbon status of soil.
Kumar and Paliyal (2016) ${ }^{[20]}$ observed that organic carbon content decreased with increase in soil depth in all the soil profiles under study. They further reported that incorporation of leaf litter and addition of decayed roots in the upper layers and their further decomposition might have resulted in accumulation of organic carbon in the surface layers. The organic carbon content decreased gradually with an increase in depth, which is mainly due to the accumulation of plant residues on the soil surface and less movement down the profile due to rapid rate of mineralization at higher temperature and adequate soil moisture level (Patangray et al., 2018) ${ }^{[35]}$. Mandal et al., (2019) ${ }^{[23]}$ reported similar vertical distribution of organic carbon content along the soil profile. Mandal and Ghosh (2020) ${ }^{[22]}$ reported low to medium organic carbon content in the surface soils of selected blocks of Birbhum district, West Bengal.

Available $\mathrm{N}$ content varied from 124.44-250.88 kg/ha in profile $1\left(\mathrm{P}_{1}\right) ; 100.35-200.70 \mathrm{~kg} / \mathrm{ha}$ in profile $2\left(\mathrm{P}_{2}\right) ; 75.26-$ $250.88 \mathrm{~kg} / \mathrm{ha}$ in profile $3\left(\mathrm{P}_{3}\right) ; 75.26-275.97 \mathrm{~kg} / \mathrm{ha}$ in profile 4 $\left(\mathrm{P}_{4}\right) ; 100.35-250.88 \mathrm{~kg} / \mathrm{ha}$ in profile $5\left(\mathrm{P}_{5}\right)$. Low to medium available $\mathrm{N}$ was observed in all five soil profiles. Decreasing trend with the depth was observed in all the profiles due to decrease in organic matter with the increasing depth (Talib and Verma, 1990). Similar results have also been reported by Sharma and Bali (2000) ${ }^{[40]}$; Thangasamy et al., (2005) ${ }^{[51]}$; Todmal et al., (2008) ${ }^{[52]}$. Studies of Sankar and Dadhwal (2009) ${ }^{[38]}$ revealed that available $\mathrm{N}$ content was maximum in surface horizon and found decreasing with increasing depth which might be due to decreasing content of organic carbon with depth. Sharma et al., (2013) ${ }^{[42]}$ reported a gradual decrease of $\mathrm{N}$ was noted down the depth in all three plains. Srinivasan et al., (2013) ${ }^{[48]}$ also reported that the available $\mathrm{N}$ status in all the pedons was rated as low to medium in cashew growing soils of Dakshina Kannada district of coastal Karnataka. Available N status was found to be maximum in surface horizons and decreased regularly with soil depth, which might possibly be due to the accumulation of plant residues, debris and rhizosphere. The available $\mathrm{N}$ gradually decreased with increasing depth of soil profile which is due to decreasing trend of organic carbon with depth (Naik, 2014) ${ }^{[29]}$. Nayak et al., (2014) ${ }^{[30]}$ have also reported higher available $\mathrm{N}$ content at the surface and a decreasing trend with depth. Gradual decrease of $\mathrm{N}$ was noted down the depth in all four pedons in soils of mid central valley at Odisha zone (Mishra et al., 2015) [25]. Kumar and Paliyal (2016) [20] observed that the surface soils were having comparatively higher $\mathrm{N}$ content than the subsurface soils. The values of available $\mathrm{N}$ decreased with the increase in profile depth. Decreasing organic matter might have contributed to the decreased available $\mathrm{N}$ content with depth. Khanday et al., (2017) ${ }^{[16]}$ revealed that the amount of available $\mathrm{N}$ ranged from medium to high and decreased with the depth in the soils of Namblan Sub-catchment of Jhelum basin of Srinagar district in Kashmir valley. High organic carbon content in the soils resulted medium to high available $\mathrm{N}$ value in all the profiles. Low $\mathrm{N}$ content in the sub-surface soils is due to low quantity of organic carbon in the soils and uncertain precipitation has a foremost impact on availability of $\mathrm{N}$ (Kumar and Sharma, 2018) ${ }^{[21]}$. All the profiles showed that the available $\mathrm{N}$ decreased with the increase in depth. Similar result was observed by Satish et al., (2018) ${ }^{[39]}$. They reported that available $\mathrm{N}$ was found to be maximum in the surface horizons and decreased more or less with depth of the pedons, which might be due to the decreasing trend in organic carbon with depth. 
Available $\mathrm{P}$ content varied from $11.53-14.41 \mathrm{~kg} / \mathrm{ha}$ in profile $1\left(\mathrm{P}_{1}\right) ; 8.65-23.78 \mathrm{~kg} / \mathrm{ha}$ in profile $2\left(\mathrm{P}_{2}\right) ; 11.53-19.50 \mathrm{~kg} / \mathrm{ha}$ in profile $3\left(\mathrm{P}_{3}\right) ; 11.53-25.22 \mathrm{~kg} / \mathrm{ha}$ in profile $4\left(\mathrm{P}_{4}\right) ; 10.81-$ $15.86 \mathrm{~kg} / \mathrm{ha}$ in profile $5\left(\mathrm{P}_{5}\right)$. According to the limits suggested by Muhr et al., (1965) ${ }^{[27]}$ soil profiles had low to medium $\mathrm{P}$ content at all three depths. The surface soils are categorized as medium and sub surface soils as low to medium in available P content. Like N, P also decreased with increase in depth. The lower $\mathrm{P}$ content in sub surface horizons could be attributed to the fixation of released $\mathrm{P}$ by clay minerals and oxides of iron and aluminum (Thangasamy et al., 2005; Nazir and Wani, 2009) ${ }^{[51,31]}$. Higher P content at surface layer and lower value at deeper layer might be due to the presence of organic matter which increases the availability of $\mathrm{P}$ in soil (Singh and Mishra, 2012) ${ }^{[44]}$. A gradual decrease of $\mathrm{P}$ was noted down the depth in all three plains in the alluvial soils of Aravalli Range (Sharma et al., 2013) ${ }^{[42]}$. Naik (2014) [29] also reported in his studies that available P gradually decreased with increasing soil depth in acidic soils of Jharkhand. Higher available P content was found in the surface horizon because of the addition of large quantities of $\mathrm{P}$ for paddy cultivation (Mishra et al., 2015) ${ }^{[25]}$. They further reported a gradual decrease of $\mathrm{P}$ was recorded down the depth in all four pedons in soils of mid central valley at Odisha zone. Kumar and Paliyal (2016) ${ }^{[20]}$ showed that available P content decreased with depth. Due to confinement of crop roots in the surface layer and supplementation of the depleted $P$ through additional phosphatic fertilizers, the surface horizons contained higher P content. Khanday et al., (2017) ${ }^{[16]}$ reported similar trend of available $\mathrm{P}$ along the soil profiles in the soils of Namblan sub-catchment of Jhelum basin of Srinagar district in Kashmir valley. Higher values of available $P$ content were observed in the surface horizons. Kunlanit $(2018)^{[3]}$ reported higher available $\mathrm{P}$ content were in top-soils $(0-15 \mathrm{~cm})$ than subsoils $(15-100 \mathrm{~cm})$ under all land uses. Satish et al., (2018) ${ }^{[39]}$ reported that the available P decreased with depth regularly.

Available K content varied from $137.55-230.02 \mathrm{~kg} / \mathrm{ha}$ in profile $1\left(\mathrm{P}_{1}\right)$; $161.94-229.25 \mathrm{~kg} / \mathrm{ha}$ in profile $2\left(\mathrm{P}_{2}\right) ; 149.95$ $310.32 \mathrm{~kg} / \mathrm{ha}$ in profile $3\left(\mathrm{P}_{3}\right) ; 160.14-252.29 \mathrm{~kg} / \mathrm{ha}$ in profile $4\left(\mathrm{P}_{4}\right) ; 161.82-181.26 \mathrm{~kg} / \mathrm{ha}$ in profile $5\left(\mathrm{P}_{5}\right)$. Available $\mathrm{K}$ content decreased with increasing depth of soil profiles. High to medium $\mathrm{K}$ content was found at surface layer in all five soil profiles. At lower depth low to medium available $\mathrm{K}$ content was observed. Most of the surface soils had higher available $\mathrm{K}$ content which might be due to more intense weathering of potash bearing minerals, generation of leaf litter from different crops in cropping systems, release of labile $\mathrm{K}$ from organic residues, application of $\mathrm{K}$ fertilizers and upward translocation of $\mathrm{K}$ from lower depth with capillary rise of ground water (Hirekurbar et al., 2000; Patil et al., 2008). The highest available $\mathrm{K}$ was observed in the surface horizons and showed more or less a decreasing trend with depth (Sireesha and Naidu, 2013). The highest available K status was noticed in the surface horizons and showed decreasing trend with depth (Srinivasan et al., 2013) ${ }^{[48]}$. Naik (2014) ${ }^{[29]}$ reported in his studies that available $\mathrm{K}$ gradually decreased with increasing depth of soil profile. Available $\mathrm{K}$ was found decreasing with increase in soil depth in all the land uses under study (Kumar and Paliyal, 2016) ${ }^{[20]}$. Khanday et al., (2017) ${ }^{[16]}$ reported medium to high available $\mathrm{K}$ content in all the soil profiles. They further reported that $\mathrm{K}$ followed decreasing trend with increasing depth. Exchangeable $\mathrm{K}$ contents were higher in topsoils $(0-15 \mathrm{~cm})$ than sub-soils $(15-$ $100 \mathrm{~cm}$ ) for all land uses (Kunlanit, 2018) ${ }^{[3]}$. Satish et al., (2018) ${ }^{[39]}$ observed medium available $\mathrm{K}$ content in surface horizon and its value showed a regular decrease with the depth. Low exchangeable $\mathrm{K}$ status is probably due to the slow weathering of mica and fixation of released $\mathrm{K}$. The higher $\mathrm{K}$ could be attributed to more intense weathering, release of liable $\mathrm{K}$ from organic residues, application of $\mathrm{K}$ fertilizers and upward translocation of $\mathrm{K}$ from lower depths along with capillary raise of ground water.

Available $S$ content varied from $1.88-3.11 \mathrm{mg} / \mathrm{kg}$ in profile 1 $\left(\mathrm{P}_{1}\right) ; 1.04-2.65 \mathrm{mg} / \mathrm{kg}$ in profile $2\left(\mathrm{P}_{2}\right) ; 1.03-2.44 \mathrm{mg} / \mathrm{kg}$ in profile $3\left(\mathrm{P}_{3}\right) ; 2.46-2.65 \mathrm{mg} / \mathrm{kg}$ in profile $4\left(\mathrm{P}_{4}\right) ; 2.11-3.01$ $\mathrm{mg} / \mathrm{kg}$ in profile $5\left(\mathrm{P}_{5}\right)$. Available $\mathrm{S}$ content decreased with increasing depth of soil profiles. Low S content was observed in all soil profiles at all three depths. Surface layers contained almost more available $S$ than subsurface layers which could be due to higher amount of organic matter in surface layers than in deeper layers and varying land use and parent material (Farida, 1997). The available $\mathrm{S}$ is more in surface horizons than the subsurface horizons in cashew growing soils of Dakshina Kannada district of coastal Karnataka (Srinivasan et al., 2013) ${ }^{[48]}$. High organic matter content in the surface horizons may be the reason for higher values of S (Khanday et al., 2017) ${ }^{[16]}$. Kumar and Sharma (2018) ${ }^{[21]}$ also reported that available $S$ decreased with the increase of depth of the soil profile. Satish et al., (2018) ${ }^{[39]}$ also reported decreasing trend of available $S$ with increasing depth of soil profiles was observed in soils of Brahmanakotkur watershed of Kurnool district in Andhra Pradesh. Due to continuous addition of farm residues, FYM and S containing fertilizers, high concentration of available $S$ was observed in the top layer of the soil profile.

Table 6: Chemical Characteristics of the Profile Soils of Selected Blocks at different Depths of Birbhum District

\begin{tabular}{|c|c|c|c|c|c|c|c|c|}
\hline \multicolumn{9}{|c|}{ 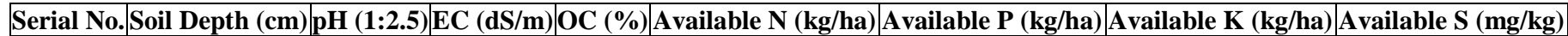 } \\
\hline \multicolumn{9}{|c|}{ Profile $1\left(\mathbf{P}_{1}\right)$ Suri II } \\
\hline $\mathrm{S}_{1}$ & $0-15$ & 5.01 & 0.06 & 0.78 & 250.88 & 14.41 & 230.02 & 3.11 \\
\hline $\mathrm{S}_{2}$ & $15-30$ & 5.46 & 0.08 & 0.39 & 225.79 & 12.25 & 165.18 & 2.06 \\
\hline $\mathrm{S}_{3}$ & $30-60$ & 6.03 & 0.10 & 0.31 & 125.44 & 11.53 & 137.55 & 1.88 \\
\hline \multicolumn{9}{|c|}{ Profile $2\left(\mathbf{P}_{2}\right)$ Rampurhat II } \\
\hline $\mathrm{S}_{4}$ & $0-15$ & 6.46 & 0.09 & 0.76 & 200.70 & 23.78 & 229.25 & 2.65 \\
\hline $\mathrm{S}_{5}$ & $15-30$ & 6.79 & 0.10 & 0.61 & 150.53 & 11.53 & 196.88 & 2.22 \\
\hline $\mathrm{S}_{6}$ & $30-60$ & 7.07 & 0.12 & 0.30 & 100.35 & 8.65 & 161.94 & 1.04 \\
\hline \multicolumn{9}{|c|}{ Profile $3\left(\mathbf{P}_{3}\right)$ Md Bazar } \\
\hline $\mathrm{S}_{7}$ & $0-15$ & 5.03 & 0.05 & 0.81 & 250.88 & 19.50 & 310.32 & 2.44 \\
\hline $\mathrm{S}_{8}$ & $15-30$ & 5.65 & 0.07 & 0.49 & 150.53 & 13.69 & 161.83 & 1.96 \\
\hline $\mathrm{S}_{9}$ & $30-60$ & 6.98 & 0.07 & 0.30 & 75.26 & 11.53 & 149.95 & 1.03 \\
\hline \multicolumn{9}{|c|}{ Profile $4\left(\mathrm{P}_{4}\right)$ Nalhati I } \\
\hline$S_{10}$ & $0-15$ & 6.42 & 0.05 & 0.81 & 275.97 & 25.22 & 252.29 & 2.65 \\
\hline $\mathrm{S}_{11}$ & $15-30$ & 6.89 & 0.07 & 0.49 & 100.35 & 18.74 & 176.05 & 2.53 \\
\hline
\end{tabular}




\begin{tabular}{|l|c|c|c|c|c|c|c|c|}
\hline $\mathrm{S}_{12}$ & $30-60$ & 6.98 & 0.07 & 0.30 & 75.26 & 11.53 & 160.14 & 2.46 \\
\hline \multicolumn{7}{|c|}{ Profile 5 (P5) Sainthia } \\
\hline $\mathrm{S}_{13}$ & $0-15$ & 5.79 & 0.07 & 0.55 & 250.88 & 15.86 & 281.26 & 3.01 \\
\hline $\mathrm{S}_{14}$ & $15-30$ & 6.02 & 0.09 & 0.47 & 100.35 & 12.97 & 170.11 & 2.25 \\
\hline $\mathrm{S}_{15}$ & $30-60$ & 6.54 & 0.10 & 0.23 & 100.35 & 10.81 & 161.82 & 2.11 \\
\hline
\end{tabular}

The correlation Coefficients between physico-chemical properties and macronutrients of collected soil profiles are represented in Table-7. $\mathrm{pH}$ showed significant and negative correlation with available $\mathrm{N}\left(\mathrm{r}=-0.696^{* *}\right)$, non-significant and negative correlation with available $\mathrm{P}(\mathrm{r}=-0.182)$, available $K \quad(r=-0.489)$ and available $S \quad(r=-0.447)$. Significant and negative correlations between soil $\mathrm{pH}$ and available N were reported by Khokhar et al., (2012) ${ }^{[17]}$; Patil et al., (2015) [37]; Bhat et al., (2017) ${ }^{[4]}$. Kumar and Paliyal (2016) ${ }^{[20]}$ reported non-significant and negative correlation between $\mathrm{pH}$ and available $\mathrm{P}(\mathrm{r}=-0.161)$ and available $\mathrm{S}(\mathrm{r}=$ 0.059 ) in cultivated lands (annual crops) in Spiti valley. In the cultivated lands (apple plantation) $\mathrm{pH}$ showed non-significant and negative correlation with available $\mathrm{N}(\mathrm{r}=-0.307), \mathrm{P}(\mathrm{r}=-$ 0.399), $\mathrm{K}(\mathrm{r}=-0.377)$ whereas significant and negative correlation was found between available $\mathrm{S}$ and $\mathrm{pH}(\mathrm{r}=$ $\left.0.585^{*}\right)$. In pasture lands $\mathrm{pH}$ correlated non-significantly and negatively with available $\mathrm{P}(\mathrm{r}=-0.712)$. Kumar and Sharma (2018) ${ }^{[21]}$ reported that available $\mathrm{N}$ correlated significantly and negatively with $\mathrm{pH}(\mathrm{r}=-0.967 * *)$ whereas $\mathrm{pH}$ correlated non-significantly negatively with available $\mathrm{P}(\mathrm{r}=-0.784)$, available $\mathrm{K}(\mathrm{r}=-0.397)$ and available $\mathrm{S}(\mathrm{r}=-0.360)$. Patangray et al., (2018) ${ }^{[35]}$ reported that $\mathrm{pH}$ showed non-significant and negative correlation with $\mathrm{N}(\mathrm{r}=-0.36)$ in soils of Yavatmal district, Maharashtra. The significant and negative correlation between soil $\mathrm{pH}$ and available $\mathrm{N}$ indicated that increase in soil $\mathrm{pH}$ decreased available $\mathrm{N}$, which might be due to volatilization loss of $\mathrm{N}$ with rise $\mathrm{pH}$ of soil.

Soil organic carbon showed significant and positive correlation with available $\mathrm{N}\left(\mathrm{r}=0.816^{* *}\right)$, available $\mathrm{P}(\mathrm{r}=$ $\left.0.771^{* *}\right)$, available $\mathrm{K}\left(\mathrm{r}=0.815^{* *}\right)$ and available $\mathrm{S}(\mathrm{r}=$ $\left.0.611^{*}\right)$. This implies that with the increase in organic carbon content of the soil, available macronutrients increase. Significant and positive correlation between available $\mathrm{N}$ and organic carbon was reported by Meena et al., (2006) ${ }^{[24]}$ in some surface soils of Tonk district of Rajasthan. Sharma et al., (2013) ${ }^{[42]}$ reported significant and positive correlation with organic carbon and available N $(r=0.519 * *)$. Significant and positive correlation was found between organic carbon and available $\mathrm{K}\left(\mathrm{r}=0.505^{* *}\right)$. Significant and positive correlation between organic carbon and available $\mathrm{N}$ might be due to the release of mineralizeable $\mathrm{N}$ from soil organic matter in proportionate amounts (Vanilarasu and Balkrishnamurthy, 2014) and absorption of ammonical $\mathrm{N}$
$\left(\mathrm{NH}_{4}-\mathrm{N}\right)$ by humus complex in the soil. Non-significant positive correlation was recorded between soil organic carbon and available $\mathrm{N}$ and $\mathrm{K}$ (Kumar et al., 2014; Bhat et al., 2017) ${ }^{[4]}$. Kumar and Paliyal (2016) ${ }^{[20]}$ reported non-significant and positive correlation between organic carbon with all macronutrients at cultivated lands (annual crops). At cultivated lands (apple plantation) organic carbon correlated significantly and positively with available $\mathrm{N}\left(\mathrm{r}=0.998^{*}\right)$, available $\mathrm{P} \quad\left(\mathrm{r}=0.782^{*}\right)$ and available $\mathrm{S}\left(\mathrm{r}=0.931^{*}\right)$. Significant and positive correlation was found between organic carbon and available $\mathrm{P}\left(\mathrm{r}=0.802^{*}\right)$, available $\mathrm{K}(\mathrm{r}=$ $\left.0.649^{*}\right)$ in pasture land. Organic carbon content showed nonsignificant and positive correlation with available $\mathrm{N}(\mathrm{r}=$ $0.767)$ and available $\mathrm{P}(\mathrm{r}=0.429)$ (Kumar and Sharma, 2018) [21]. Similar results were given by Meena et al., (2006) ${ }^{\text {[24]; }}$ Sharma et al., (2008) [41]; Kumar et al., (2009). Patangray et al., (2018) ${ }^{[35]}$ reported that soil organic carbon showed nonsignificant and positive correlation with $\mathrm{N}(\mathrm{r}=0.63)$, available $\mathrm{K}(\mathrm{r}=0.16)$, available $\mathrm{P}(\mathrm{r}=0.20)$. Non-significant positive correlation between \% OC and available $\mathrm{P}$ might be due to acidulating effect of organic carbon, formation of easily accessible organophosphate complexes, release of $\mathrm{P}$ from organic complexes and reduction in $\mathrm{P}$ fixation by humus due to formation of coatings on iron and aluminum oxides. They further reported that the increase in availability of $S$ by organic carbon may be attributed to release of $\mathrm{S}$ from organic complexes as well as acidulating action of soil organic carbon thus enhancing the weathering of minerals containing S. Similar results were reported by Pareek (2007) ${ }^{[34]}$; Bhat et al., $(2017)^{[4]}$.

EC showed significant and negative correlation with available $\mathrm{N} \quad\left(\mathrm{r}=-0.514^{*}\right)$ whereas non-significant and negative correlation was recorded between EC and available P ( $\mathrm{r}=$ $0.093)$, available $\mathrm{K}(\mathrm{r}=-0.450)$, and available $\mathrm{S}(\mathrm{r}=-0.205)$. Somasundaram et al., (2013) ${ }^{[47]}$; Kartikeyan et al., (2014) ${ }^{[15]}$ reported non-significant negative correlation between EC and available N and available P. Kumar and Sharma (2018) ${ }^{[21]}$ reported non-significant and negative correlation between EC and available $\mathrm{N}(\mathrm{r}=-0.876)$, available $\mathrm{K}(\mathrm{r}=-0.526)$, available $\mathrm{S}(\mathrm{r}=-0.605)$ whereas significant and negative correlation was recorded between EC and available P $\left(r=-0.906^{*}\right)$. Nonsignificant and negative correlation was found between available $\mathrm{N}$ and EC ( $\mathrm{r}=-0.06)$ (Patangray et al., 2018) ${ }^{[35]}$.

Table 7: Correlation Coefficients lbetween physico-chemical properties and Macronutrients of collected soil profiles

\begin{tabular}{|c|c|c|c|c|c|c|c|}
\hline Parameters & $\mathbf{p H}$ & $\mathbf{E C}$ & $\mathbf{O C}$ & Available N & Available P & Available K & Available S \\
\hline $\mathrm{pH}$ & 1 & & & & & \\
\hline EC & $0.821^{* *}$ & 1 & & & & \\
\hline OC & $-0.519^{*}$ & -0.468 & 1 & & & \\
\hline Available N & $-0.696^{* *}$ & $-0.514^{*}$ & $0.816^{* *}$ & 1 & & \\
\hline Available P & -0.182 & -0.093 & $0.771^{* *}$ & $0.618^{*}$ & 1 & & \\
\hline Available K & -0.489 & -0.450 & $0.815^{* *}$ & $0.812^{* *}$ & $0.667^{* *}$ & 1 & \\
\hline Available S & -0.447 & -0.205 & $0.611^{*}$ & $0.624^{*}$ & $0.576^{*}$ & $0.636^{*}$ & \\
\hline
\end{tabular}

*. Correlation is significant at the 0.05 level. **. Correlation is significant at the 0.01 level

\section{Conclusion}

The vertical distribution of available macronutrients in selected soil profiles of Birbhum district, West Bengal as discussed above indicated that soils were having low to medium available $\mathrm{N}$ and $\mathrm{P}$, low $\mathrm{S}$ content, high to medium $\mathrm{K}$ content in surface layer whereas lower value at lower depth. 
The soils were strongly acidic to neutral in reaction and nonsaline in nature. The study revealed that the available macronutrients viz., N, P, S, K in general decreased with depth in all soil profiles. Higher values of macronutrients in the surface layer were observed in the profiles due to high organic carbon content which was mostly influenced by plant residues on the soil surface and less movement down the profile. Due to the nutrient recycling by the plants, all soil profiles showed decrease in available macronutrient content with increasing depth. The content of macronutrients increased with increase in organic carbon and decreased with increase in $\mathrm{pH}$ and EC. Supplementing the deficient nutrients by applying chemical fertilizers and/or organic manures improves the soil health and sustainable paddy production in these soils. The generated information could be used for managing appropriate fertilizer application in case of both deep and shallow rooted crops.

\section{Acknowledgements}

One of the authors (S. M.) gratefully acknowledges the award of a Junior Research Fellow (JRF)/ Senior Research Fellow (SRF) by the University Grants Commission, New Delhi for their financial support to carry out the present research work. Authors are thankful to the Head of the Department of Soil Science and Agricultural Chemistry and also to the Dean, Faculty of Agriculture, Visva-Bharati, Sriniketan, for providing necessary laboratory facilities and their cooperation and support.

\section{References}

1. Arora CL. Analysis of soil, plant and fertilizers. In fundamental of soil science (Sekhon GS, Chhonkar PK, Das DK, Goswami NN, Narayanasamy G, Poonia SR, Rattan RK, Sehgal J, Eds.), Indian Society of Soil Science, New Delhi 2002.

2. Balpande HS, Challa O, Prasad J. Characterization and classification of Grape-growing soils in Nasik district, Maharastra. Journal of the Indian Society of Soil Science 2007;55:80-83.

3. Benjapon Kunlanit B. Distribution of some macronutrients in soil profiles as influenced by land use changes. Khon Kaen Agricultural Journal 2018;46(Suppl.1).

4. Bhat ZA, Padder SA, Ganaie AQ, Dar NA, Rehman HU, Wani MY. Correlation of vailable nutrients with physico chemical properties and nutrient content of grape orchards of Kashmir. Journal of Pharmacognosy and Phytochemistry 2017;6(2):181-185.

5. Boke S. Soil phosphorus fractions as influenced by different cropping systems in Andosols and Nitosols in Kembata-Tembaro and Wolayta Zones, SNNPRS. MSc Thesis. Alemaya University, (AU) 2004, 131.

6. Bouyoucos GJ. The Hydrometer as a new method for the mechanical analysis of soils. Soil Science 1927;23:343353.

7. Bray RH, Kurtz LT. Determination of total organic carbon and available forms of phosphorous in soils. Soil Science 1945;59:39-45.

8. Chima UD. Effects of tropical rainforest modification on soil quality of Omo biosphere reserve in Ogun State, Nigeria. (Master of Forestry (M.F) Dissertation, University of Agriculture, Abeokuta, Ogun state, Nigeria) 2007.

9. Durak A, Buyukguner E, Dogan HM. Determination of Physical and Chemical Properties of the Soils under
Different Land Managements. Asian Journal of Chemistry 2010;22(8):6375-6386.

10. Farida A. Evaluation of sulphur in some paddy growing soils of Kashmir. M. Sc Thesis submitted to SKUAST Kashmir Srinagar 1997, 1-102.

11. Hariram, Dwivedi KN. Delineation of sulphur deficient soil groups in the central alluvial tract of Uttar Pradesh. Journal of the Indian Society of Soil Science 1994;42:284-286.

12. Hirekurbar BT, Satyanarayan T, Sarangmath PA, Manjunathaiah HM. Forms of potassium and their distribution in soils under cotton based cropping system in Karnataka. Journal of the Indian Society of Soil Science 2000;48(3):604-608.

13. Jackson ML. Soil chemical analysis. Prentice Hall India Private Limited. New Delhi 1973, 498.

14. Jiang Y, Zang G, Zou D, Qin Y, Liang WJ. Profile distribution of micronutrients in an aquic brown soil as affected by land use. Plant, Soil and Environment 2009;155(11):468-476.

15. Kartikeyan K, Pushpanjali Prasad J. Soil fertility status of soybean (Glycine $\max$ L.) growing soils of Malwa plateau, Madhya Pradesh. Journal of the Indian Society of Soil Science 2014;62(2):170-178.

16. Khanday MUD, Ram D, Wani JA, Ali T. Vertical Distribution of Nutrient of the Soils of Namblan Sub Catchment of Jhelum Basin of Srinagar District in Kashmir Valley. International Journal of Current Microbiology and Applied Sciences 2017;6(4):375-381.

17. Khokhar Y, Singh H, Rattanpal L, Dhillon WS, Singh G, Gill PS. Soil fertility and nutritional status of Kinnow orchards grown in aridisol of Punjab, India. African Journal of Agricultural Research 2012;7(3):4692-4697.

18. Kumar R, Sarkar AS, Singh KP, Agarwal BK, Karmakar S. Appraisal of available nutrients status in Santhal Paraganas region of Jharkhand. Journal of the Indian Society of Soil Science 2009;57(3):366-369.

19. Kumar A, Mishra VN, Srivastav LK, Banwasi R. Evaluation of soil fertility status of available major nutrients $(\mathrm{N}, \mathrm{P}$ and $\mathrm{K})$ and micronutrients $(\mathrm{Fe}, \mathrm{Mn}, \mathrm{Cu}$ and $\mathrm{Zn}$ ) in vertisols of Kabeerdham district of Chhattisgrah, India. International Journal of Interdisciplinary and Multidisciplinary Studies 2014;1(2):72-79.

20. Kumar R, Paliyal SS. Vertical Distribution of Available macronutrients in relation to Physico-chemical properties under different land uses of cold arid soils of Spiti valley in Himachal Pradesh. The Ecoscan 2016;10(3\&4):579584.

21. Kumar V, Sharma KR. Macronutrients distribution in submontnae soils of the Jammu in relation to soil properties. International Journal of Chemical Studies 2018;6(3):2263-2270.

22. Mandal, Sunandana, Ghosh GK. Distribution of DTPAextractable Micronutrients and their Relationship with Some Soil Properties in Rice growing soils of Birbhum District, West Bengal, India. Proceedings of II. International Agricultural, Biological \& Life Science Conference (E-AGBIOL 2020 - ISBN \#: 978-975-374279-5 Edited by Prof. Dr. Yalcin Kaya), Trakya University Publisher No: 237, Edirne, Turkey 2020, 570593.

23. Mandal, Sunandana, Mondal S, Mukherjee A, Mukhopadhyay S, Ghosh GK. Vertical distribution of DTPA-Extractable micronutrients and its correlation with 
soil properties in selected soil profiles of Birbhum district of West Bengal. Science and Culture 2019;85(7-8): 281290.

DOI: https://doi.org/10.36094/scienceandculture.v85.2019.Man dal. 281

24. Meena HB, Sharma RP, Rawat US. Status of Macro- and Micronutrients in Some Soils of Tonk District of Rajasthan. Journal of the Indian Society of Soil Science 2006;54(4):508-512.

25. Mishra A, Pattnaik TM, Das D, Das M. Vertical Distribution of Available Plant Nutrients in Soils of Mid Central Valley at Odisha Zone, India. American Journal of Experimental Agriculture 2015;7(4):214-221.

26. Mondal D. Ek Najare Birbhum Jela, Paschim Banga, Birbhum Special Issue (in Bengali) 2006, 7-10.

27. Muhr GR, Datta NP, Sankara, Subramoney H, Liley VK, Donahue RR. Soil testing in India. US Agency for International Development, New Delhi 1965.

28. Nagendran T, Alagu, Angayarkanni A. Vertical Distribution of DTPA- Extractable Micronutrients in Soils of Cumbum Valley, Tamil Nadu. Agricultural Science Digest 2010;30(2):79-84.

29. Naik SK. Distribution of Nitrogen, Phosphorus, Potassium and Zinc content in Mango grown acidic soils of Jharkhand. The Ecoscan 2014;8(1\&2):135-139.

30. Nayak Tripti T, Bajpai RK. Influence of organic and inorganic fertilization on soil physical properties in arid soils under wheat. The Ecoscan 2014;9(1\&2):71-74.

31. Nazir S, Wani MA. Forms of potassium and potassium absorption behavior of soil under different cropping sequences. SKUAST Journal of Research 2009;11(2):133-137.

32. Oladoye AO. Physicochemical properties of soil under two different depths in a tropical forest of international institute of tropical agriculture, Abeokuta, Ibadan, Nigeria. Journal of Research in Forestry, Wildlife and Environmental 2015;7(1):40-54.

33. Olsen SR, Cole RV, Watanabe FS, Dean LA. Estimation of available phosphorus in soils by extraction with sodium bicarbonate. Circular Circular, Vol 939 (p. 19). Washington, DC: US Department of Agriculture 1954.

34. Pareek N. Soil mineralize able sulphur a sulphur availability index. Journal of the Indian Society of Soil Science 2007;3:289-293.

35. Patangray AJ, Patil NG, Pagdhune AR, Singh SK, Mishra VN. Vertical distribution of soil nutrients and its correlation with chemical properties in soils of Yavatmal district, Maharashtra. Journal of Pharmacognosy and Phytochemistry 2018;7(6):2799-2805.

36. Patil GD, Khedkar VR, Tathe AS, Deshpande AN. Characterization and classification of soils of Agricultural College Farm, Pune. Journal of Maharashtra Agricultural Universities 2008;33(2):143-148.

37. Patil RB, Saler RS, Gaikwad VB. Nutritional survey of different vineyards in Nashik district. Maharashtra Journal of Basic Sciences 2015;1:6-12.

38. Sankar M, Dadhwal KS. Vertical distribution of available macro and micronutrients cation in red soils of Tamil Nadu. Asian Journal of Soil Science 2009;4(1):118-120.

39. Satish S, Naidu MVS, Ramana KV. Vertical distribution of available nutrients in soils of Brahmanakotkur watershed of Kurnool district in Andhra Pradesh. International Journal of Chemical Studies 2018;6(5):2916-2925.
40. Sharma MP, Bali SV. Long-term effect of different cropping ststems on physicochemical properties and soil fertility. Journal of the Indian Society of Soil Science 2000;18(1):183-185.

41. Sharma PK, Sood A, Setia RK, Tur NS, Mehra D, Singh H. Mapping of macronutrients in soils of Amritsar district (Punjab) A GIS approach. Journal of the Indian Society of Soil Science 2008;56(1):34-41.

42. Sharma RP, Singh RS, Sharma SS. Vertical Distribution of Plant Nutrients in Alluvial Soils of Aravalli Range and Optimization of Land Use RP. International Journal of Pharmaceutical and Chemical Sciences 2013;2(3):13771389.

43. Sireesha PVG, Naidu MVS. Studies on genesis, characterization and classification of soils in semi-arid Agro-ecological region: A case study in Banaganapalle mandal of Kurnool district, Andhra Pradesh. Journal of the Indian Society of Soil Science 2013;61(3):167-178.

44. Singh RP, Mishra SK. Available macronutrients (N, P, K and $\mathrm{S}$ ) in the soils of Chiraigaon Block of District Varanasi (U.P) in relation to soil Charecteristics. Indian Journal of Scientific Research 2012;3(1):97-100.

45. Singh KS, Haribhushan A, Akoijam SS. Soil Macro- and Micro-Nutrient status of Chandel District, ManipurIndia. International Journal of Agriculture Sciences 2017;9:4107-4109.

46. Smith JL, Elliot LF. Tillage and residue management effects on soil organic matter dynamics in semiarid reigns. Advances in Soil Science 1990;13:70-80.

47. Somasundaram J, Singh RK, Parandiyal AK, Ali Shakir, Chauhan V, Sinha Nishant K et al. Soil Properties under different land use systems in parts of Chambal region of Rajasthan. Journal of Agricultural Physics 2013;13(2):139-147.

48. Srinivasan R, Natarajan A, Kumar KS, Anil Kalaivanan D. Distribution of Available Macro and Micronutrients in Cashew Growing Soils of Dakshina Kannada District of Coastal Karnataka. Madras Agricultural Journal 2013;100(1-3):747-750.

49. Subbiah BV, Asija GL. A rapid procedure for estimation of available nitrogen in soil. Current Science 1956;25:259-260.

50. Talib AR, Verma SD. Relationship between different forms of potassium and particle size in bench mark soil of Kashmir. Indian Journal of Agricultural Science 1990;60(9):643-644.

51. Thangasamy A, Naidu MVS, Ramaratharamand N, Raghava Reddy C. Characterization and classification and evaluation of soil resources in Sivagiri Microwatershed of Chittor district in Andhra Pradesh for sustainable land use planning. Journal of the Indian Society of Soil Science 2005;53(1):11-21.

52. Todmal SM, Patil BP, Tamboli BD. Characterisation and classification of soils in Agriculture College Farm, Kolhapur. Journal of Maharashtra agricultural Universities 2008;33(3):287-291.

53. Vanilarasu K, Balakrishnamurthy G. Influences of organic manures and amendments in soil physiochemical properties and their impact on growth, yield and nutrient uptake of banana. The Bioscan 2014;9(2):525-529.

54. Walkley A, Black CA. An examination of digestion methods for determining soil organic matter and a proposed modification of the chromic acid titration method. Soil Science 1934;37(1):29-38. 
55. Williams $\mathrm{CH}$, Steinbergs A. Soil sulphur interactions as chemical indices of available sulphur in some Australian soils. Australian Journal of Agricultural Research 1959;10:340-352.

56. Wong MTF, van der Kruijs ACBM, Juo ASR. Leaching loss of calcium, magnesium, potassium and nitrate derived from soil, lime and fertilizers as influenced by urea applied to undisturbed lysimeters in south-east Nigeria. Nutrient Cycling in Agroecosystems 2005;31:281-289. 